\title{
PENGARUH MACAM DAN WAKTU APLIKASI BAHAN ORGANIK \\ PADA TANAMAN UBI JALAR (Ipomoea batatas L.) Var. KAWI
}

\section{EFFECT OF KIND AND APPLICATION TIME OF ORGANIC MATTER ON SWEET POTATO (Ipomoea batatas L.) Var. KAWI}

\author{
Nur Edy Suminarti ${ }^{1}$ dan Susanto ${ }^{2}$ \\ ${ }^{1}$ Dosen Fakultas Pertanian Universitas. Brawijaya, Malang \\ ${ }^{2}$ Alumni Fakultas Pertanian Universitas Brawijaya, Malang \\ Jl. Veteran, Malang 65145 Jawa Timur, Indonesia \\ Korespondensi : nuredys@gmail.com
}

Diterima 25 Maret 2015 /Disetujui 13 Mei 2015

\begin{abstract}
ABSTRAK
Diversifikasi pangan merupakan langkah tepat untuk mengantisipasi kondisi rawan pangan. Hal ini menjadi penting karena setiap tahun luas lahan basah telah mengalami penyusutan sekitar $0,1 \%$ dari total luas lahan di Indonesia. Sehubungan dengan hal tersebut, dan dalam upaya untuk memenuhi kebutuhan pangan nasional, maka pemanfaatan ubi jalar sebagai sumber bahan pangan alternatif perlu dilakukan. Penelitian yang bertujuan untuk mendapatkan informasi tentang macam dan waktu aplikasi bahan organik yang tepat telah dilakukan di Desa Landungsari, Kabupaten Malang. Rancangan yang digunakan adalah Petak Terpisah, macam bahan organik ditempatkan pada petak utama, terdiri dari 3 macam, yaitu pupuk kandang sapi, kompos azolla dan kompos sampah kota. Waktu aplikasi bahan organik sebagai anak petak, terdiri dari 3 macam, yaitu : 30 hari sebelum tanam, 15 hari sebelum tanam dan bersamaan tanam. Pengumpulan data dilakukan secara destruktif, meliputi komponen pertumbuhan dan panen, analisis pertumbuhan tanaman dan analisis tanah. Uji $F$ taraf $5 \%$ ditujukan untuk menguji pengaruh perlakuan, sedang perbedaan diantara rata-rata perlakuan didasarkan pada nilai BNT taraf $5 \%$. Interaksi nyata terjadi pada sebagian besar parameteryang diamati, dan hasil umbi tertinggi didapatkan pada kompos sampah kota yang waktu aplikasinya dilakukan 30 hari sebelum tanam : 28,03 ton umbi ha-1 .
\end{abstract}

Kata kunci: Bahan organik, Ubi jalar, Waktu aplikasi

\begin{abstract}
Food diversification is a precise step to anticipate food shortage condition. It becomes important because wetland area is decreasing of approximately $0,1 \%$ each year of total area in Indonesia. Related to that point, also in order to meet food national demand, utilization of sweet potato as alternative food resource needs to be done. Research aimed to get information about proper kind and application time of organic matter had been done at Landungsari, Malang. The design used was Split Plot, kind of organic matter was placed as main plot, consisting of 3 kinds, ie: cow manure, azzola compost, and urban waste compost. Application time was set as subplot, consisting of 3 times, ie: 30 days before planting, 15 days before planting, and simultaneous with planting. Data collection was carried out destructively,
\end{abstract}


including growth and yield components, plant growth analysis and soil analysis. $F$ test on $5 \%$ level intended to test treatment effect, meanwhile difference between mean values based on LSD 5\%. Real interaction occurred on almost all parameters observed, moreover the highest tuberyield was on urban waste compost which time application was 30 days before planting : 28,03 ton tuber ha ${ }^{-1}$.

Key words : Application time, Organic matter, Sweet potato

\section{PENDAHULUAN}

Ubi jalar termasuk komoditas umbiumbian yang mempunyai prospek penting. Hal ini selain karena tingginya kandungan nutrisi, mineral dan vitamin, juga semakin beragamnya produk olahan maupun industri yang bersumber dari ubi tersebut. Ubi jalar dapat dimanfaatkan sebagai bahan baku tepung, nasi instan, bakpia, donat, keripik, mie dan beras mutiara. Tepung ubi jalar dapat juga diolah menjadi berbagai produk pangan seperti permen, es krim, roti, kue dan beberapa minuman sirup. Sebagai sumber bahan pangan alternatif, ubi jalar dapat dikonsumsi dengan cara digoreng atau direbus. Berdasarkan pada tingginya pemanfaatan ubi jalar tersebut, mengakibatkan permintaan terhadap ubi jalar terus meningkat. Oleh karena itu, untuk mengimbangi terjadinya peningkatan permintaan, dan dalam upaya untuk menjaga kontinuitas ketersediaan ubi jalar, maka perlu dilakukan pengembangan. Umumnya pengembangan tanaman pertanian diarahkan pada pemanfaatan lahan kering, dan hal ini cukup beralasan karena luas lahan basah telah mengalami reduksi.

Lahan kering sebenarnya merupakan suatu lahan yang cukup potensial untuk dikembangkannya berbagai jenis tanaman, mulai dari tanaman yang merambat, perdu hingga tanaman yang bertajuk tinggi ( Undang dkk, 2004). Tetapi, karena tingginya kendala yang harus dihadapi dalam usahatani lahan kering, mengakibatkan lahan tersebut kurang mendapat perhatian. Adapun kendala yang umum terjadi pada lahan kering adalah : (1) terbatasnya tingkat ketersediaan air tanah, (2) rendahnya tingkat kesuburan tanah, dan (3) kurang mendukungnya sifat fisik tanah.

Umumnya lahan kering didominasi oleh liat atau debu, sehingga tanah bersifat padat atau sangat ringan. Tanah yang demikian umumnya kurang baik dalam mendukung proses pertumbuhan dan perkembangan tanaman, karena akan mengganggu proses perkembangan perakaran tanaman, selain tanah tidak dapat menyimpan dan memegang air dengan baik. Akar merupakan salah satu organ penting tanaman yang berfungsi daLam penyerapan air dan nutrisi bagi tanaman. Oleh karena itu, apabila sistem perakaran terganggu, maka proses metabolisme tanaman juga akan terganggu. Sedangkan, air merupakan senyawa penting yang diperlukan tanaman sebagai unsur pelarut, yaitu untuk melarutkan unsur hara sehingga dapat diserap tanaman. Air juga berfungsi dalam mengatur membuka menutupnya stomata melalui pengaturan turgiditas sel penjaga. Pada saat air cukup tersedia bagi tanaman, maka stomata akan membuka sebagai akibat terjadinya penggelembungan sel penjaga, sehingga kegiatan fotosintesa terjadi. Tetapi ketika kondisi air terbatas, maka stomata akan menutup dan fotosintesa tidak terjadi. 
Mengingat pentingnya peranan air ini, maka ketersediaan air yang cukup bagi tanaman sangat diperlukan.

Tanaman ubi jalar termasuk jenis tanaman yang hasil ekonomisnya terletak di dalam tanah, sehingga kondisi fisik tanah yang dapat mendukung proses pembentukan dan perkembangan umbi sangat diperlukan. Diketahui bahwa struktur tanah lahan kering umumnya gumpal hingga gumpal bersudut yang dicirikan dengan agregat berpegang erat dengan lainnya, sehingga akan dapat mengganggu proses pembentukan dan perkembangan umbi. Berdasar pada kondisi tersebut dan dalam upaya pemanfaatan lahan kering untuk kegiatan pertanian, maka perbaikan sifat fisik tanah perlu dilakukan, yaitu melalui aplikasi bahan organik.

Bahan organik merupakan kompleks gabungan antara jasad hidup, mati, bahan terdekomposisi dan senyawa organik yang dapat berperan memperbaiki sifat phisik, kimia dan biologi tanah (Suriadikarta dkk, 2005). Namun demikian, besar kecilnya sumbangan bahan organik yang diaplikasikan ke tanah tersebut akan sangat dipengaruhi oleh sumber dan waktu aplikasi bahan organik. Bahan organik yang bersumber dari pupuk kandang sapi, kompos azolla dan kompos sampah kota, akan memiliki sumbangan berbeda yang akan diberikan kepada tanah, tergantung dari komponen penyusun dari bahan organik tersebut.

Kompos azolla dengan komponen penyusun utama adalah nitrogen, maka $\mathrm{N}$ yang dibebaskan ke tanah juga akan lebih banyak dibandingkan pupuk kandang sapi maupun kompos sampah kota yang komponen penyusun utamanya adalah unsur K (Hakim dkk, 1986). Kalium terlibat dalam pembentukan dinding sel, dan dinding sel ini merupakan makro molekul yang panjang yang bersifat kaku dan sukar larut dalam air, sehingga untuk bahan organik yang penyusun utamanya unsur tersebut, mempunyai kecepatan dekomposisi lambat yang dicirikan dengan tingginya nilai $\mathrm{C} / \mathrm{N}$ dari bahan organik tersebut. Pada kondisi $\mathrm{C} / \mathrm{N}$ tinggi (> 15), terjadi persaingan penggunaan $\mathrm{N}$ antara tanaman dengan jasad mikro, $\mathrm{N}$ disini akan dimanfaatkan oleh jasad mikro sebagai sumber energi untuk perkembangbiakkannya, sehingga $\mathrm{N}$ di in-mobilisasikan. Akibatnya $\mathrm{N}$ menurun sekali dalam tanah hingga proses humifikasi selesai. Tetapi, ketika $\mathrm{N}$ sudah tidak diperlukan lagi oleh jasad mikro, maka proses nitrifikasi terjadi kembali, dan ketersediaan $\mathrm{N}$ dalam tanah meningkat. Pada kondisi demikian ini $\mathrm{C} / \mathrm{N}$ menjadi rendah (Putri dkk, 2013). Berdasar pada hal tersebut diatas, maka waktu aplikasi bahan organik memegang peran penting dalam kaitannya proses dekomposisi bahan organik. Bahan organik dengan $\mathrm{C} / \mathrm{N}$ tinggi ( $>15$ ) diperlukan waktu aplikasi yang lebih awal dibandingkan dengan bahan organik yang mempunyai $\mathrm{C} / \mathrm{N}$ rendah $(<10)$.

Berdasar pada permasalahan tersebut di atas, maka penelitian tentang macam dan waktu aplikasi bahan organik pada tanaman ubi jalar perlu untuk dilakukan dalam upaya untuk meningkatkan dan menjaga kontinuitas hasil tanaman ubi jalar, khususnya di lahan kering.

\section{BAHAN DAN METODE}

Penelitian yang bertujuan untuk mendapatkan informasitentang macam dan waktu aplikasi bahan organik yang tepat 
telah dilakukan pada bulan April sampai dengan September 2013 di Desa Landungsari, Kabupaten Malang. Rancangan perlakuan yang digunakan adalah Petak terpisah, macam bahan organik ditempatkan pada petak utama, terdiri dari 3 macam, yaitu : pupuk kandang sapi, kompos azolla dan kompos sampah kota. Waktu aplikasi bahan organik ditempatkan pada anak petak, terdiri dari 3 macam, yaitu : 30 hari sebelum tanam, 15 hari sebelum tanam dan bersamaan tanam. Penentuan dosis bahan organik didasarkan pada hasil analisis tanah awal dan analisis dari masingmasing bahan organik.

Pengumpulan data dilakukan secara destruktif, meliputi : komponen pertumbuhan, yaitu bobot kering akar, jumlah daun, luas daun, dan bobot kering total tanaman, dan panen meliputi bobot umbi per tanaman dan hasil ton ha ${ }^{-1}$. Analisis pertumbuhan tanaman, yaitu Indeks pembagian serta analisis tanah yang meliputi analisis tanah awal (sebelum aplikasi bahan organik), analisis tanah tengah (setelah aplikasi bahan organik) dan analisis tanah akhir (setelah panen). Uji F taraf $5 \%$ ditujukan untuk menguji pengaruh perlakuan, sedang perbedaan diantara ratarata perlakuan didasarkan pada nilai BNT taraf 5\% (Gomez and Gomez, 1983).

HASIL

Interaksi nyata terjadi antara macam dan waktu aplikasi bahan organik pada seluruh parameter yang diamati yang mencakup komponen pertumbuhan, panen dan perhitungan analisis pertumbuhan tanaman.

\section{Komponen pertumbuhan}

\section{Bobot kering akar}

Akar merupakan organ tanaman yang penting selain daun, sehingga dengan semakin banyak akar yang terbentuk, maka semakin berat bobot akar yang dihasilkan, dan semakin banyak pula air dan unsur hara yang dapat diserap tanaman. Pada Tabel 1 disajikan rerata bobot kering akar pada tiga macam bahan organik dan tiga macam waktu aplikasi.

Tabel 1. Rerata bobot kering akar (g) pada tiga macam bahan organik dan tiga macam waktu aplikasi pada saat tanaman berumur 65 hst.

\begin{tabular}{lccc}
\hline \multirow{2}{*}{ Perlakuan } & \multicolumn{3}{c}{ Waktu aplikasi bahan organik } \\
\cline { 2 - 4 } & Bersamaan tanam & $\begin{array}{c}15 \text { hari sebelum } \\
\text { tanam }\end{array}$ & $\begin{array}{c}\text { 30 hari sebelum } \\
\text { tanam }\end{array}$ \\
\hline Macam bahan organik & $0,26 \mathrm{a}$ & $0,29 \mathrm{ab}$ & $0,33 \mathrm{~b}$ \\
Pupuk kandang sapi & $\mathrm{A}$ & $\mathrm{A}$ & $\mathrm{A}$ \\
Kompos azolla & $0,37 \mathrm{a}$ & $0,40 \mathrm{ab}$ & $0,42 \mathrm{~b}$ \\
Kompos sampah kota & $\mathrm{B}$ & $\mathrm{B}$ & $\mathrm{B}$ \\
& $0,48 \mathrm{a}$ & $0,56 \mathrm{~b}$ & $0,66 \mathrm{c}$ \\
BNT 5\% & $\mathrm{C}$ & $\mathrm{C}$ & $\mathrm{C}$ \\
\hline
\end{tabular}

Keterangan : Bilangan yang didampingi huruf yang sama pada kolom yang sama atau baris yang sama menunjukkan tidak berbeda nyata berdasarkan uji BNT taraf $p=5 \%$. hst : hari setelah tanam 
Tabel 1 memperlihatkan bahwa bobot kering akar akibat aplikasi pupuk kandang sapi, kompos azolla maupun kompos sampah kota yang waktu aplikasinya dilakukan bersamaan tanam adalah lebih rendah $21,21 \%, 11,90 \%$ dan $27,27 \%$ jika dibandingkan dengan waktu aplikasi 30 hari sebelum tanam. Tetapi untuk pupuk kandang sapi dan kompos azolla yang waktu aplikasinya dilakukan bersamaan tanam dan 15 hari sebelum tanam, bobot kering akar yang dihasilkan tidak berbeda nyata, dan hal ini terjadi pula ketika kedua macam bahan organik tersebut diaplikasikan 15 dan 30 hari sebelum tanam. Pada kompos sampah kota, setiap perubahan waktu aplikasi mengakibatkan peningkatan bobot kering akar masing-masing sebesar $16,67 \%$ dari bersamaan tanam menjadi 15 hari sebelum tanam, sebesar $17,86 \%$ dari 15 hari sebelum tanam menjadi 30 hari sebelum tanam, dan sebesar $37,5 \%$ dari bersamaan tanam menjadi 30 hari sebelum tanam.

Selanjutnya, apabila dilihat berdasarkan waktu aplikasinya, maka bobot kering akar paling berat didapatkan pada penggunaan kompos sampah kota yang waktu aplikasinya dapat dilakukan pada berbagai waktu. Pengurangan bobot kering akar terjadi ketika dilakukan perubahan penggunaan bahan organik yaitu dari kompos sampah kota menjadi kompos azolla, dan dari kompos azolla menjadi pupuk kandang sapi, maupun dari kompos sampah kota menjadi pupuk kandang sapi. Pengurangan tersebut masing-masing sebesar $22,92 \%, 29,73 \%$ dan $45,83 \%$ untuk waktu aplikasi bersamaan tanam, dan sebesar $28,57 \%, 27,50 \%$ dan $48,21 \%$ untuk waktu aplikasi 15 hari sebelum tanam serta $36,36 \%, 21,43 \%$ dan $50 \%$ untuk waktu aplikasi 30 hari sebelum tanam.

\section{Jumlah daun}

Daun merupakan tempat untuk berlangsungnya kegiatan fotosintesa tanaman, sehingga banyak sedikitnya jumlah daun yang dihasilkan sangat berpengaruh pada banyak sedikitnya asimilat yang dihasilkan. Rerata jumlah daun akibat terjadinya interaksi nyata antara macam dan waktu aplikasi bahan organik disajikan pada Tabel 2.

Tabel 2. Rerata jumlah daun pada tiga macam bahan organik dan tiga macam waktu aplikasi pada saat tanaman berumur $65 \mathrm{hst}$.

\begin{tabular}{lccc}
\hline \multirow{2}{*}{ Perlakuan } & \multicolumn{3}{c}{ Waktu aplikasi bahan organik } \\
\cline { 2 - 4 } & Bersamaan tanam & $\begin{array}{c}15 \text { hari sebelum } \\
\text { tanam }\end{array}$ & $\begin{array}{c}30 \text { hari sebelum } \\
\text { tanam }\end{array}$ \\
\hline Macam bahan organik & $49,67 \mathrm{a}$ & $51,33 \mathrm{~b}$ & $52,00 \mathrm{~b}$ \\
Pupuk kandang sapi & $\mathrm{A}$ & $\mathrm{A}$ & $\mathrm{A}$ \\
Kompos azolla & $53,67 \mathrm{a}$ & $55,83 \mathrm{~b}$ & $60,33 \mathrm{c}$ \\
Kompos sampah kota & $\mathrm{B}$ & $\mathrm{B}$ & $\mathrm{B}$ \\
& $64,50 \mathrm{a}$ & $69,83 \mathrm{~b}$ & $70,67 \mathrm{~b}$ \\
\hline BNT 5\% & $\mathrm{C}$ & $\mathrm{C}$ & $\mathrm{C}$ \\
\hline
\end{tabular}

Keterangan : Bilangan yang didampingi huruf yang sama pada kolom yang sama atau baris yang sama menunjukkan tidak berbeda nyata berdasarkan uji BNT taraf $p=5 \%$. hst : hari setelah tanam 
Penggunaan pupuk kandang sapi maupun kompos sampah kota memperlihatkan pola yang sama pada berbagai waktu aplikasi terhadap jumlah daun yang dihasilkan. Jumlah daun yang lebih banyak didapatkan ketika kedua bahan organik tersebut diaplikasikan 15 dan 30 hari sebelum tanam, dan keduanya menghasilkan jumlah daun lebih banyak 4,69\% dan 3,34\% untuk pupuk kandang sapi, dan 9,7\% dan $8,26 \%$ untuk kompos sampah kota dibandingkan dengan bahan organik yang waktu aplikasinya dilakukan bersamaan tanam. Tetapi, jumlah daun yang dihasilkan oleh tanaman yang dipupuk kandang sapi maupun kompos sampah kota yang waktu aplikasinya dilakukan 15 dan 30 hari sebelum tanam tersebut adalah tidak berbeda nyata. Pada kompos azolla, jumlah daun paling banyak didapatkan ketika kompos tersebut diaplikasikan 30 hari sebelum tanam, dan memperlihatkan terjadinya pengurangan sebesar $7,46 \%$ dan $11,04 \%$ dengan dirubahnya waktu aplikasi dari 30 hari sebelum tanam, menjadi 15 hari sebelum tanam maupun dari 30 hari sebelum tanam menjadi bersamaan tanam.
Hal yang serupa juga terjadi ketika waktu aplikasi dirubah dari 15 hari sebelum tanam menjadi bersamaan tanam.

Selanjutnya apabila dilihat berdasarkan waktu aplikasinya, maka jumlah daun paling banyak umumnya didapatkan pada perlakuan kompos sampah kota, dan memperlihatkan terjadinya pengurangan dengan dirubahnya macam bahan organik tersebut, yaitu dari kompos sampah kota menjadi kompos azolla maupun menjadi pupuk kandang sapi. Pengurangan tersebut masing-masing sebesar $16,79 \%$ dan $22,99 \%$ untuk waktu aplikasi bersamaan tanam, dan 20,05\% dan $26,49 \%$ untuk waktu aplikasi 15 hari sebelum tanam serta $14,63 \%$ dan $26,42 \%$ untuk waktu aplikasi 30 hari sebelum tanam. Pengurangan jumlah daun juga terjadi ketika penggunaan kompos azolla dirubah menjadi pupuk kandang sapi.

\section{Luas daun}

Pada Tabel 3 disajikan rerata luas daun pada berbagai sumber bahan organik dan waktu aplikasinya.

Tabel 3. Rerata luas daun $\left(\mathrm{cm}^{2}\right)$ pada tiga macam bahan organik dan tiga macam waktu aplikasi pada saat tanaman berumur 65 hst.

\begin{tabular}{lccc}
\hline \multirow{2}{*}{ Perlakuan } & \multicolumn{3}{c}{ Waktu aplikasi bahan organik } \\
\cline { 2 - 4 } & Bersamaan tanam & $\begin{array}{c}15 \text { hari sebelum } \\
\text { tanam }\end{array}$ & $\begin{array}{c}\text { 30 hari sebelum } \\
\text { tanam }\end{array}$ \\
\hline Macam bahan organik & 1058,42 a & 1088,15 a & $1163,33 \mathrm{~b}$ \\
Pupuk kandang sapi & $\mathrm{A}$ & $\mathrm{A}$ & $\mathrm{A}$ \\
Kompos azolla & $1278,50 \mathrm{a}$ & $1390,47 \mathrm{~b}$ & $1659,92 \mathrm{c}$ \\
& $\mathrm{B}$ & $\mathrm{B}$ & $\mathrm{B}$ \\
Kompos sampah kota & 1841,94 a & $1992,21 \mathrm{~b}$ & $2047,67 \mathrm{c}$ \\
& $\mathrm{C}$ & $\mathrm{C}$ & 50,15 \\
\hline BNT 5\% & \multicolumn{3}{c}{} \\
\hline Keterangan : Bilangan yang didampingi huruf yang sama pada kolom yang sama atau baris yang sama \\
menunjukkan tidak berbeda nyata berdasarkan uji BNT taraf $\mathrm{p}=5 \%$.
\end{tabular}


Tabel 3 memperlihatkan bahwa luas daun paling luas umumnya didapatkan pada semua macam bahan organik yang waktu aplikasinya dilakukan 30 hari sebelum tanam. Pengubahan waktu aplikasi, yaitu dari 30 hari sebelum tanam menjadi 15 hari sebelum tanam, maupun menjadi bersamaan tanam mengakibatkan lebih sempitnya luas daun yang dihasilkan, dan pengurangan luas daun paling besar didapatkan ketika waktu aplikasi dirubah dari 30 hari sebelum tanam menjadi bersamaan tanam, masing-masing sebesar 9,02\% untuk pupuk kandang sapi, 22,98\% untuk kompos azolla dan 10,05\% untuk kompos sampah kota. Sedangkan apabila dilihat dari pengaruh waktu aplikasi pada penggunaan macam bahan organik, maka luas daun paling luas didapatkan pada penggunaan kompos sampah kota, dan memperlihatkan terjadinya pengurangan dengan digantinya penggunaan macam bahan organik, baik dari kompos sampah kota menjadi kompos azolla dan dari kompos sampah kota menjadi pupuk kandang sapi, maupun dari kompos azolla menjadi pupuk kandang sapi.

\section{Bobot Kering Total Tanaman}

Bobot kering total tanaman mencerminkan asimilat yang dapat dihasilkan tanaman, dan pada Tabel 4 disajikan rerata bobot kering total tanaman akibat aplikasi macam bahan organik dan waktu aplikasinya.

Tabel 4. Rerata bobot kering total tanaman (g) pada tiga macam bahan organik dan tiga macam waktu aplikasi pada saat tanaman berumur 65 hst.

\begin{tabular}{|c|c|c|c|}
\hline \multirow[b]{2}{*}{ Perlakuan } & \multicolumn{3}{|c|}{ Waktu aplikasi bahan organik } \\
\hline & $\begin{array}{c}\text { Bersamaan } \\
\text { tanam }\end{array}$ & $\begin{array}{c}15 \text { hari sebelum } \\
\text { tanam }\end{array}$ & $\begin{array}{c}30 \text { hari sebelum } \\
\text { tanam }\end{array}$ \\
\hline Macam bahan organik & & & \\
\hline Pupuk kandang sapi & $\begin{array}{c}17,31 \mathrm{a} \\
\mathrm{A}\end{array}$ & $\begin{array}{c}18,97 a b \\
A\end{array}$ & $\begin{array}{c}21,40 \mathrm{~b} \\
\mathrm{~A}\end{array}$ \\
\hline Kompos azolla & $\begin{array}{c}23,78 \mathrm{a} \\
\mathrm{B}\end{array}$ & $\begin{array}{c}25,73 a b \\
B\end{array}$ & $\begin{array}{c}28,41 \mathrm{~b} \\
B\end{array}$ \\
\hline Kompos sampah kota & $\begin{array}{c}33,49 \text { a } \\
\quad C\end{array}$ & $\begin{array}{c}39,68 b \\
C\end{array}$ & $\begin{array}{c}47,97 \mathrm{c} \\
\mathrm{C}\end{array}$ \\
\hline
\end{tabular}

Keterangan : Bilangan yang didampingi huruf yang sama pada kolom yang sama atau baris yang sama menunjukkan tidak berbeda nyata berdasarkan uji BNT taraf $p=5 \%$.

hst : hari setelah tanam

Tabel 4 memperlihatkan bahwa penggunaan pupuk kandang sapi dan kompos azolla yang waktu aplikasinya dilakukan 15 hari sebelum tanam maupun 30 hari sebelum tanam, bobot kering total tanaman yang dihasilkan tidak berbeda nyata. Hal ini diperlihatkan pula pada kedua macam bahan organik tersebut yang waktu aplikasinya dilakukan 15 hari sebelum tanam dan saat bersamaan tanam. Tetapi, untuk waktu aplikasi 30 hari sebelum tanam, bobot kering total tanaman yang dihasilkan nyata lebih berat $23,63 \%$ untuk pupuk kandang sapi, dan $19,47 \%$ untuk kompos azolla jika dibandingkan dengan bahan organik yang waktu aplikasinya 
dilakukan bersamaan tanam. Selanjutnya apabila dilihat berdasarkan waktu aplikasinya, maka bobot kering total tanaman yang paling berat pada berbagai waktu aplikasi didapatkan pada penggunaan kompos sampah kota, yang kemudian diikuti oleh penggunaan kompos azolla dan terakhir adalah pupuk kandang sapi.

\section{PANEN}

\section{Bobot Umbi per Tanaman}

Umbi merupakan bagian ekonomis pada tanaman ubi jalar, dan pembentukannya sangat dipengaruhi oleh banyaknya asimilat yang dihasilkan tanaman maupun oleh tinggi rendahnya nilai indeks pembagian. Pada Tabel 5 disajikan rerata bobot umbi per tanaman pada tiga macam bahan organik dan tiga macam waktu aplikasi.

Tabel 5. Rerata bobot umbi per tanaman (g) pada tiga macam bahan organik dan tiga macam waktu aplikasi pada saat panen

\begin{tabular}{lccc}
\hline \multirow{2}{*}{ Perlakuan } & \multicolumn{3}{c}{ Waktu aplikasi bahan organik } \\
\cline { 2 - 4 } & $\begin{array}{c}\text { Bersamaan } \\
\text { tanam }\end{array}$ & $\begin{array}{c}15 \text { hari sebelum } \\
\text { tanam }\end{array}$ & $\begin{array}{c}30 \text { hari sebelum } \\
\text { tanam }\end{array}$ \\
\hline Macam bahan organik & $248,53 \mathrm{a}$ & $286,13 \mathrm{ab}$ & $320,33 \mathrm{~b}$ \\
Pupuk kandang sapi & $\mathrm{A}$ & $\mathrm{A}$ & $\mathrm{A}$ \\
Kompos azolla & $381,47 \mathrm{a}$ & $400,20 \mathrm{ab}$ & $430,80 \mathrm{~b}$ \\
Kompos sampah kota & $\mathrm{B}$ & $\mathrm{B}$ & $\mathrm{B}$ \\
& $448,40 \mathrm{a}$ & $448,47 \mathrm{a}$ & $588,60 \mathrm{~b}$ \\
\hline BNT 5\% & $\mathrm{C}$ & $\mathrm{C}$ & $\mathrm{C}$ \\
\hline
\end{tabular}

Keterangan : Bilangan yang didampingi huruf yang sama pada kolom yang sama atau baris yang sama menunjukkan tidak berbeda nyata berdasarkan uji BNT taraf $p=5 \%$. hst : hari setelah tanam

Bobot umbi pertanaman yang dihasilkan oleh tanaman yang dipupuk kandang sapi maupun kompos azolla dengan waktu aplikasi 15 hari dan 30 hari sebelum tanam adalah tidak berbeda nyata. Kejadian yang serupa juga diperlihatkan pada waktu aplikasi 15 hari sebelum tanam dan bersamaan dengan tanam. Namun demikian, untuk waktu aplikasi 30 hari sebelum tanam, bobot umbi per tanaman yang dihasilkan nyata lebih berat $28,89 \%$ untuk pupuk kandang sapi dan $12,93 \%$ untuk kompos azolla jika dibandingkan bila waktu aplikasi yang dilakukan bersamaan tanam. Sedang pada perlakuan kompos sampah kota, bobot umbi paling berat didapatkan pada waktu aplikasi 30 hari sebelum tanam, dan memperlihatkan terjadinya penurunan ketika waktu aplikasi dirubah, yaitu dari 30 hari sebelum tanam menjadi 15 hari sebelum tanam maupun menjadi bersamaan tanam. Penurunan bobot umbi tersebut masing - masing sebesar $23,81 \%$ dan $23,82 \%$. Bobot umbi memperlihatkan hasil yang tidak berbeda nyata ketika waktu aplikasi kompos sampah kota dilakukan 15 hari sebelum tanam dan bersamaan dengan tanam.

Secara umum, bobot umbi per tanaman paling tinggi pada berbagai waktu aplikasi didapatkan pada penggunaan kompos sampah kota, dan memperlihatkan terjadinya penurunan ketika terjadi penggantian macam bahan organik, yaitu 
dari kompos sampah kota menjadi kompos azolla, dan dari kompos sampah kota menjadi pupuk kandang sapi, maupun dari kompos azolla menjadi pupuk kandang sapi. Penurunan bobot umbi tersebut masingmasing sebesar $5,92 \%, 44,57 \%$ dan $34,85 \%$ untuk waktu aplikasi bersamaan tanam, $10,76 \%, 36,20 \%$ dan $28,50 \%$ untuk waktu aplikasi 15 hari sebelum tanam dan $26,81 \%$, 45,58\% dan 25,64\% untuk waktu aplikasi 30 hari sebelum tanam.

\section{Hasil umbi per hektar}

Pada Tabel 6 disajikan rerata hasil umbi per hektar pada tiga macam bahan organik dan tiga macam waktu aplikasi

Tabel 6. Rerata hasil umbi per hektar (ton) pada tiga macam bahan organik dan tiga macam waktu aplikasi pada saat panen

\begin{tabular}{lccc}
\hline \multirow{2}{*}{ Perlakuan } & \multicolumn{3}{c}{ Waktu aplikasi bahan organik } \\
\cline { 2 - 4 } & $\begin{array}{c}\text { Bersamaan } \\
\text { tanam }\end{array}$ & $\begin{array}{c}15 \text { hari sebelum } \\
\text { tanam }\end{array}$ & $\begin{array}{c}\text { 30 hari sebelum } \\
\text { tanam }\end{array}$ \\
\hline Macam bahan organik & $11,84 \mathrm{a}$ & $13,63 \mathrm{~b}$ & $15,25 \mathrm{c}$ \\
Pupuk kandang sapi & $\mathrm{A}$ & $\mathrm{A}$ & $\mathrm{A}$ \\
Kompos azolla & $18,16 \mathrm{a}$ & $19,06 \mathrm{~b}$ & $20,51 \mathrm{c}$ \\
Kompos sampah kota & $\mathrm{B}$ & $\mathrm{B}$ & $\mathrm{B}$ \\
& $21,35 \mathrm{a}$ & $23,26 \mathrm{~b}$ & $28,03 \mathrm{c}$ \\
\hline BNT 5\% & $\mathrm{C}$ & $\mathrm{C}$ & $\mathrm{C}$ \\
\hline
\end{tabular}

Keterangan : Bilangan yang didampingi huruf yang sama pada kolom yang sama atau baris yang sama menunjukkan tidak berbeda nyata berdasarkan uji BNT taraf $p=5 \%$. hst : hari setelah tanam

Tabel 6 memperlihatkan bahwa hasil umbi per hektar tertinggi pada berbagai macam bahan organik didapatkan ketika waktu aplikasinya dilakukan 30 hari sebelum tanam, dan memperlihatkan terjadinya penurunan dengan dirubahnya waktu aplikasi bahan organik. Pengubahan waktu aplikasi dari 30 hari sebelum tanam menjadi 15 hari sebelum tanam, dan dari 30 hari sebelum tanam menjadi bersamaan tanam, maupun dari 15 hari sebelum tanam menjadi bersamaan tanam, mengakibatkan menurunnya hasil umbi masing-masing sebesar 1,62 ton ha $^{-1}(10,62 \%), 3,41$ ton ha ${ }^{-1}$ ( 22,36\%) dan 1,79 ton ha ${ }^{-1}(13,13 \%)$ untuk pupuk kandang sapi, dan sebesar 1,45 ton ha $^{-1}(7,07 \%), 2,35$ ton ha ${ }^{-1}(11,46 \%)$ serta 0,9 ton ha $^{-1}(4,72 \%)$ untuk kompos azolla, dan sebesar 4,77 ton ha $^{-1}(17,02 \%), 6,68$ ton ha ${ }^{-1}(23,83 \%)$ dan 1,91 ton ha ${ }^{-1}(8,21 \%)$ untuk kompos sampah kota.

Sedangkan apabila dilihat dari pengaruh waktu aplikasi pada berbagai macam bahan organik, maka hasil umbi per hektar tertinggi didapatkan pada penggunaan kompos sampah kota, dan memperlihatkan terjadinya penurunan dengan diubahnya macam bahan organik yang digunakan. Pengubahan macam bahan organik dari kompos sampah kota, menjadi kompos azolla maupun menjadi pupuk kandang sapi serta dari kompos azolla menjadi pupuk kandang sapi mengakibatkan menurunnya hasil umbi masing-masing sebesar $14,94 \%$, 44,54\% dan 34,80\% untuk waktu aplikasi bersamaan tanam, dan sebesar $18,06 \%$, 41,40\% dan 23,34\% untuk waktu aplikasi 15 hari sebelum tanam, serta sebesar $26,83 \%$, 
45,59\% dan 25,65\% untuk waktu aplikasi 30 hari sebelum tanam.

\section{Analisis pertumbuhan Tanaman}

\section{Indeks Pembagian (IP)}

Interaksi nyata tidak terjadi antara macam dan waktu aplikasi bahan organik pada parameter Indeks Pembagian. Namun demikian, Indeks Pembagian sangat dipengaruhi oleh macam bahan organik yang digunakan (Tabel 7).

Tabel 7. Rerata nilai indeks pembagian (\%) pada tiga macam bahan organik dan tiga macam waktu aplikasi pada saat panen

\begin{tabular}{|c|c|}
\hline Perlakuan & $\mathrm{IP}(\%)$ \\
\hline \multicolumn{2}{|l|}{ Macam bahan organik } \\
\hline Pupuk kandang sapi & 58,03 a \\
\hline Kompos azolla & $59,44 a b$ \\
\hline Kompos sampah kota & $60,62 b$ \\
\hline BNT 5\% & 1,83 \\
\hline \multicolumn{2}{|l|}{$\begin{array}{l}\text { Waktu aplikasi bahan } \\
\text { organik }\end{array}$} \\
\hline Bersamaan tanam & 59,44 \\
\hline $\begin{array}{l}15 \text { hari Sebelum } \\
\text { tanam }\end{array}$ & 58,99 \\
\hline $\begin{array}{l}30 \text { hari Sebelum } \\
\text { tanam }\end{array}$ & 59,67 \\
\hline BNT 5\% & tn \\
\hline $\begin{aligned} \text { eterangan : } & \text { Bilangan } \\
& \text { yang sama } \\
& \text { menunjukk } \\
& \text { berdasarka } \\
& \text { tn : tidak b }\end{aligned}$ & $\begin{array}{l}\text { didampingi huru } \\
\text { kolom yang same } \\
\text { ak berbeda nyata } \\
\text { 3NT taraf p }=5 \% \\
\text { nyata }\end{array}$ \\
\hline
\end{tabular}

Indeks pembagian menggambarkan banyaknya asimilat yang dialokasikan ke bagian ekonomis (umbi) dari total asimilat yang dihasilkan. Semakin tinggi nilai indeks pembagian, berarti semakin banyak pula asimilat yang dialokasikan ke bagian umbi. Tabel 7 memperlihatkan bahwa nilai indeks pembagian yang dihasilkan oleh tanaman yang diberi kompos sampah kota adalah tidak berbeda nyata dengan tanaman yang dipupuk kompos azolla. Hal ini diperlihatkan pula pada perlakuan kompos azolla dan pupuk kandang sapi. Namun demikian, nilai indeks pembagian yang dihasilkan oleh tanaman yang dipupuk kandang sapi adalah nyata lebih rendah $4,27 \%$ jika dibandingkan dengan tanaman yang dipupuk kompos sampah kota.

\section{PEMBAHASAN}

Hasil akhir suatu tanaman merupakan fungsi dari pertumbuhan, dan pertumbuhan tanaman sangat dikendalikan oleh 3 faktor, yaitu : (1) faktor lingkungan, (2) faktor genetik, dan (3) faktor manajemen. Apabila diketahui faktor genetik bukan merupakan kendala dalam budidaya tanaman, maka pertumbuhan dan hasil tanaman sangat dipengaruhi oleh faktor lingkungan dan manajemen. Sitompul dan Guritno (1995) menyatakan bahwa lingkungan dan tanaman merupakan kesatuan yang tidak dapat dipisahkan. Oleh karena itu, agar tanaman dapat tumbuh berkembang dengan baik dan dapat menyelesaikan siklus hidupnya secara utuh, maka diperlukan lingkungan yang optimum. Pada dasarnya faktor lingkungan dibedakan menjadi lingkungan atas tanah dan lingkungan bawah tanah yang mencakup tanah, air dan unsur hara. Tanah merupakan tempat tegaknya tanaman, selain sebagai penyedia air dan nutrisi bagi tanaman. Oleh karena itu, agar tanah dapat mendukung proses perkembangan tanaman, maka kondisi tanah yang baik secara fisik, kimia dan biologi sangat diperlukan (Andayani dan Sarido, 2013).

Hasil penelitian menunjukkan bahwa secara umum interaksi nyata terjadi pada seluruh parameter yang diamati, kecuali indeks panen. Pengaruh macam bahan organik pada berbagai waktu aplikasi memperlihatkan bahwa umumnya hasil yang lebih tinggi didapatkan pada bahan organik yang waktu aplikasinya dilakukan 30 hari sebelum tanam. Hal ini cukup 
dimengerti karena besar kecilnya dampak yang diberikan kepada tanah akibat aplikasi bahan organik sangat dipengaruhi oleh macam dan tingkat kecepatan proses dekomposisi bahan organik tersebut. Sedangkan cepat tidaknya proses dekomposisi sangat dipengaruhi oleh tinggi rendahnya nilai $\mathrm{C} / \mathrm{N}$. Bahan organik dengan $\mathrm{C} / \mathrm{N}$ tinggi ( $>15$ ) menunjukkan dekomposisi belum lanjut atau baru mulai (Kastono, 2005). Oleh karena itu, agar bahan organik yang diaplikasikan tersebut dapat memberikan manfaat pada perubahan sifat fisik tanah, maka diperlukan waktu aplikasi lebih awal, yaitu 30 hari sebelum tanam.

Hasil analisis contoh tanah awal yang telah dilakukan memberi informasi bahwa secara fisika, lahan percobaan mempunyai tekstur liat berdebu dengan komposisi pasir, debu dan liat masing-masing sebesar 9\% : 41\% : 50\%. Tanah dengan tekstur liat berdebu mempunyai sifat berat dan melekat sehingga tanah mempunyai sifat rendah dalam menyimpan dan memegang air. Namun demikian, tekstur tersebut telah mengalami perubahan setelah diaplikasikannya bahan organik, dan berdasarkan hasil analisis contoh tanah akhir(setelah panen) yang telah dilakukan, memperlihatkan terjadinya perubahan dari proporsi pasir, debu dan liat dari ketiga waktu aplikasi.

Namun demikian, untuk bahan organik yang waktu aplikasinya dilakukan bersamaan tanam, kandungan liatnya paling tinggi (40\%), sementara kandungan pasirnya paling rendah (8\%) bila dibandingkan dengan waktu aplikasi 15 dan 30 hari sebelum tanam (Tabel 8 ). Tingginya kadar liat tersebut berdampak pada rendahnya kemampuan akar untuk berkembang, sehingga bobot akar yang dihasilkan rendah (Tabel 1). Di sisi lain diperlihatkan bahwa bobot kering akar tertinggi pada berbagai waktu aplikasi didapatkan pada perlakuan kompos sampah kota. Hal ini terjadi sebagai akibat rendahnya nilai $\mathrm{C} / \mathrm{N}$ dari kompos sampah kota tersebut, yaitu 3 .

Tabel 8. Pengaruh macam dan waktu aplikasi bahan organik terhadap tekstur tanah (Lab.Fisika dan Kimia Tanah, Jurusan Ilmu Tanah Fakultas Pertanian UB, 2013)

\begin{tabular}{|c|c|c|c|c|}
\hline \multirow[t]{2}{*}{ Perlakuan (Kode) } & \multicolumn{3}{|c|}{ Proporsi (\%) } & \multirow[t]{2}{*}{ Tekstur } \\
\hline & Pasir & Debu & Liat & \\
\hline Tanah awal & 9 & 41 & 50 & Liat berdebu \\
\hline \multicolumn{5}{|c|}{ Tanah akhir (setelah panen) : } \\
\hline $\mathrm{B}_{1} \mathrm{~W}_{1}$ & 8 & 60 & 32 & Lempung liat berdebu \\
\hline $\mathrm{B}_{1} \mathrm{~W}_{2}$ & 9 & 55 & 36 & Lempung liat berdebu \\
\hline $\mathrm{B}_{1} \mathrm{~W}_{3}$ & 9 & 53 & 38 & Lempung liat berdebu \\
\hline $\mathrm{B}_{2} \mathrm{~W}_{1}$ & 11 & 51 & 38 & Lempung liat berdebu \\
\hline $\mathrm{B}_{2} \mathrm{~W}_{2}$ & 10 & 57 & 33 & Lempung liat berdebu \\
\hline $\mathrm{B}_{2} \mathrm{~W}_{3}$ & 8 & 54 & 38 & Lempung liat berdebu \\
\hline $\mathrm{B}_{3} \mathrm{~W}_{1}$ & 7 & 69 & 24 & Lempung liat berdebu \\
\hline $\mathrm{B}_{3} \mathrm{~W}_{2}$ & 6 & 72 & 22 & Lempung berdebu \\
\hline $\mathrm{B}_{3} \mathrm{~W}_{3}$ & 6 & 69 & 25 & Lempung berdebu \\
\hline
\end{tabular}

Keterangan: $B_{1}$ : pupuk kandang sapi, $B_{2}$ : kompos azolla, $B_{3}$ : kompos sampah kota, $W_{1}$ : waktu aplikasi bersamaan tanam, $W_{2}$ : waktu aplikasi 15 hari sebelum tanam dan $W_{3}$ : waktu aplikasi 30 hari sebelum tanam 
Tabel 8 memperlihatkan bahwa aplikasi kompos sampah kota mampu memberikan perubahan terhadap tekstur tanah, yaitu dari liat berdebu (hasil analisis contoh tanah sebelum tanam) menjadi lempung berdebu (hasil analisis tanah setelah panen). Tanah dengan tekstur lempung berdebu mempunyai sifat agak melekat, sedang tanah dengan tekstur liat berdebu mempunyai sifat melekat sekali dan pada kondisi kering sukar dispirit. $\mathrm{Hal}$ ini mengindikasikan bahwa tanah dengan tekstur lempung berdebu lebih baik daripada liat berdebu, maupun lempung liat berdebu yang mempunyai sifat melekat. Tanah yang mempunyai sifat sangat melekat dan melekat, umumnya sukar memegang dan menyimpan air secara baik, selain dapat menghambat proses perkembangan perakaran tanaman (Lumbanraja, 2012). Akibatnya akar yang terbentuk sedikit dan bobot akar yang dihasilkan rendah. Rendahnya bobot kering akar tersebut mengindikasikan rendahnya kemampuan akar dalam menyerap unsur hara dan air, baik yang disebabkan oleh tingginya hambatan yang dialami oleh akar (tanah bersifat keras dan padat) maupun akibat rendahnya unsur hara yang tersedia di dalam tanah sebagai akibat belum berlanjutnya proses dekomposisi.

Hasil analisis contoh tanah tengah yang dilakukan setelah aplikasi bahan organik menunjukkan bahwa bahan organik yang waktu aplikasinya dilakukan bersamaan tanam, kandungan $\mathrm{N}$-total tanah, Kandungan P-tanah dan K-total tanah yang dihasilkan paling rendah, dan menunjukkan terjadinya peningkatan dengan lebih awalnya aplikasi bahan organik. Rendahnya pelepasan $\mathrm{N}, \mathrm{P}, \mathrm{K}$ tanah tersebut mempengaruhi tingkat ketersediaan $\mathrm{N}, \mathrm{P}, \mathrm{K}$ tanah, dan akhirnya akan berdampak pada rendahnya serapan $\mathrm{N}, \mathrm{P}, \mathrm{K}$ oleh tanaman. Suminarti (2011) mendapatkan bahwa terdapat hubungan yang erat antara pemupukan $N \quad(X)$ dengan tingkat ketersediaan hara $(\mathrm{Y})$ yang diberikan melalui suatu persamaan : $Y=0,407 \mathrm{X}-$ $0,319, R^{2}=0,99 *$. Hal ini mengindikasikan bahwa $99 \%$ tingkat ketersediaan hara di dalam tanah sangat dipengaruhi oleh banyak sedikitnya unsur hara yang ada di dalam tanah. Selanjutnya diinformasikan pula bahwa banyak sedikitnya tingkat ketersediaan hara di dalam tanah juga berpengaruh pada tingkat estimasi serapannya. Pada Tabel 9 disajikan kandungan $\mathrm{N}, \mathrm{P}, \mathrm{K}$ tanah pada berbagai macam bahan organik dan waktu aplikasinya.

Tingginya serapan hara yang terjadi pada tanaman yang dipupuk kompos sampah kota, maupun bahan organik lain yang waktu aplikasinya dilakukan 30 hari sebelum tanam menyebabkan lebih baiknya proses metabolisme tanaman yang dapat ditunjukkan melalui tingginya hasil pengukuran jumlah daun (Tabel 2) maupun luas daun (Tabel 3).

Daun merupakan organ penting tanaman, karena sebagai tempat untuk berlangsungnya kegiatan fotosintesa tanaman. Oleh karena itu, dengan semakin banyak jumlah maupun luas daun hingga batas tertentu, akan diikuti pula oleh penambahan asimilat secara proporsional (Putra, 2013). Asimilat dapat digambarkan melalui pengukuran bobot kering total tanaman, dan berdasarkan Tabel 4, bobot kering total tanaman tertinggi didapatkan pada perlakuan kompos sampah kota dan pada waktu aplikasi 30 hari sebelum tanam. Asimilat adalah suatu energi, energi tersebut sebagian akan digunakan untuk energi pertumbuhan dan sebagian akan 
disimpan sebagai sink (umbi), dan banyak sedikitnya asimilat yang dialokasikan ke bagian sink tersebut sangat ditentukan oleh tinggi rendahnya nilai indeks panen (IP). Indeks Panen menurut Suminarti (2011) merupakan rasio antara hasil ekonomis (umbi) dengan total asimilat yang dihasilkan, semakin tinggi nilai indeks panen, maka semakin banyak pula asimilat yang dialokasikan ke bagian umbi. Tabel 7 memperlihatkan bahwa pada perlakuan kompos sampah kota maupun pada perlakuan aplikasi 30 hari sebelum tanam, nilai indeks panen menunjukkan lebih tinggi, dan lebih tingginya nilai indeks panen tersebut berdampak pada bobot umbi per tanaman (Tabel 5) maupun hasil panen per hektar yang dihasilkan (Tabel 6).

Tabel 9. Kandungan N,P, K tanah awal, tengah (setelah aplikasi bahan organik ), akhir (setelah panen) dan estimasi serapannya

\begin{tabular}{cccc}
\hline Macam bahan organik/analisis ke: & \multicolumn{3}{c}{ Kandungan unsur } \\
\cline { 2 - 4 } & $\begin{array}{c}\mathrm{N} \text {-total } \\
(\%)\end{array}$ & $\begin{array}{c}\mathrm{P} \text { Bray } \\
\left(\mathrm{mg} \mathrm{kg}^{-1}\right)\end{array}$ & $\begin{array}{c}\mathrm{K} \\
\left({\left.\mathrm{me} 100 \mathrm{~g}^{-1}\right)}^{-1}\right.\end{array}$ \\
\hline 1. Analisis contoh tanah awal & 0,13 & 5,03 & 0,62 \\
\hline
\end{tabular}

2. Analisis contoh tanah tengah (setelah aplikasi seluruh bahan organik)

A. Waktu aplikasi

$\begin{array}{llll}\text { Bersamaan tanam } & 0,28 & 13,66 & 2,59 \\ 15 \text { hari sebelum tanam } & 0,34 & 16,87 & 2,25 \\ \text { 30 hari sebelum tanam } & 0,37 & 22,10 & 2,89 \\ \text { Macam bahan organik } & & & \\ \text { Pupuk kandang sapi, C/N 19 } & 0,26 & 8,67 & 1,50 \\ \text { Kompos azolla, C/N 13 } & 0,36 & 16,33 & 1,75 \\ \text { Kompos sampah kota,C/N 3 } & 0,37 & 27,63 & 4,47\end{array}$

Lab.Fisika dan Kimia Tanah, Jurusan Ilmu Tanah Fakultas Pertanian UB, 2013

\section{SIMPULAN}

Berdasar pada hasil penelitian tersebut, maka dapat disimpulkan bahwa :

1. Waktu aplikasi 30 hari sebelum tanam pada semua macam bahan organik menghasilkan pertumbuhan (bobot kering akar, jumlah daun, luas daun maupun bobot kering total tanaman) terbaik, dan hasil umbi (bobot umbi per tanaman maupun hasil umbi per hektar) tertinggi, masing-masing sebesar 15,25 ton ha ${ }^{-1}$ untuk pupuk kandang sapi, 20,51 ton ha ${ }^{-1}$ untuk kompos azolla dan 28,03 ton ha ${ }^{-1}$ untuk kompos sampah kota.
2. Penggunaan kompos sampah kota pada berbagai waktu aplikasi menghasilkan pertumbuhan (bobot kering akar, jumlah daun, luas daun maupun bobot kering total tanaman) terbaik, dan hasil umbi (bobot umbi per tanaman maupun hasil umbi per hektar) tertinggi, masingmasing sebesar 21,35 ton ha ${ }^{-1}$ untuk waktu aplikasi bersamaan tanam, 23,26 ton ha $^{-1}$ untuk waktu aplikasi 15 hari sebelum tanam, dan 28,03 ton ha ${ }^{-1}$ untuk waktu aplikasi 30 hari sebelum tanam 


\section{DAFTAR PUSTAKA}

Andayani dan L. Sarido. 2013. Uji Empat Jenis Pupuk kandang Pada pertumbuhan dan Hasil Tanaman Cabai keriting (Capsicum annum L.). Jurnal Agrifor 7 (1) : $22-29$

Gomez, A.A dan A.K.Gomez. 1983. Statistical Procedures for Agricultural Research. $2^{\text {nd }}$ Ed. John Wiey \& Sons. New York.

Hakim, M.Y.Nyakpa, A.M. Lubis dan M.M. Diha. 1986. Dasar-dasar Ilmu Tanah. Penerbit Universitas Lampung 1986.

Kastono,D. 2005. Tanggapan pertumbuhan dan Hasil Kedelai hitam terhadap penggunaan Pupuk Organik dan Biopestisida Siam. Jurnal Ilmu Pertanian. $12(2): 103-116$

Lumbanraja,P. 2012. Pengaruh Pemberian Pupuk Kandang Sapid an Jenis Mulsa terhadap Kapasitas Pegang Air dan Pertumbuhan Tanaman Kedelai (Glycine Max L.) var. Wilis pada Tanah Ultisol Simalingkar. Jurnal IImiah Pendidikan Tinggi. 5 (2) : $58-72$

Putra, D.F. 2013. Pengaruh Pemberian berbagai Bentuk Azolla dan Pupuk N pada Pertumbuhan dan Hasil Tanaman Jagung manis ( Zea mays saccharata Sturt). Jurnal Produksi Tanaman . 1 (3): $53-60$

Putri, F.D, H.T Sebayang dan T. Sumarni, 2013. Pengaruh Pupuk N,P,K, Azolla (Azolla Pinnata) dan Kayu Apu (Pistia Stratiotes) pada Pertumbuhan dan Hasil Tanaman Padi Sawah (Oryza sativa). Jurnal Produksi Tanaman. 1 (3) : 1-13
Sitompul, S.M dan B.Guritno, 1995. Analisis Pertumbuhan Tanaman. Gajah mada University Press. Yogjakarta

Suminarti, N.E. 2011. Teknik Budidaya Tanaman Talas (Colocasia esculenta (L). Schott var. Antiquorum pada Kondisi Kering dan Basah. Disertasi. Program Studi Ilmu Pertanian, Minat Agronomi. Program Pasca Sarjana, Univ. Brawijaya.

Suriadikarta, D.A., T.Prihatini, D. Setyorini dan W. Hartatik. 2005. Teknologi Pengelolaan Bahan Organik Tanah. Pusat Penelitian dan Pengembangan Tanah dan Agroklimat. Badan Penelitian dan Pengembangan Pertanian, Departemen Pertanian. Jakarta

Undang, K., A.Rachman dan Ai Dariah. 2004. Konservasi Tanah Pada Lahan Kering Berlereng. Pusat Penelitian dan Pengembangan Tanah dan Agroklimat. Badan Penelitian dan Pengembangan Pertanian, Departemen Pertanian. Jakarta. 